\title{
ФУНКЦІЙНО-СЕМАНТИЧНА ДИФЕРЕНЦІАЦІЯ КОНСТРУКЦІЙ 3 ПАРТИКУЛОЮ (НЕ)ХАЙ
}

Стаття присвячена актуальному для сучасної лінгвістики питанню розменування модально орієнтованих конструкиій однакового структурно-граматичного типу з огляду на функиійно-семантичну різнорідність. Запропоновано перелік основних модальних значень, здатних реалізовуватися засобом синтаксичних конструкиій із предикатом у формі дієслова спонукального способу з партикулою (не)хай. Звернено увагу на потребу розрізнення спонукальних і неспонукальних конструкцій з дотриманням тривимірного погляду на природу синтаксичної одиниці.

Ключові слова: модальність, модальне значення, спонукальна конструкиія, предикативна основа, аналітична форма дієслова, структурно-граматичний тип, функційно-семантичний тип.

Umrykhina L. Functional-semantic Differentiation of the Structures with Particle (ne)khay. The article is devoted to the relevant for modern linguistics issue of delimitation of modally oriented constructions of the same structural-grammatical type taking into account their functional-semantic diversity. The mentioned constructions require a detailed study also due to the small amount of theoretical works on these issues, which leads to the absence of definitive questions regarding their unambiguous qualification.

The purpose is to identify the grammatical and modal essence of structures with the particle (ne)khay. The task is to determine the specifics of the semantic content and features of the functioning of the statements as speech representatives of modal types, to characterize the features of the speech situation, relevant for the implementation of incentive and non-incentive structures. The list of the basic modal meanings which are capable to be realized by means of syntactic structures with a predicate in the analytical verb form is offered. The author focuses on the need to distinguish between incentive and non-incentive structures taking into account the three-dimensional conception of the nature of a syntactic unit.

Syntactic structures with a predicate, actualized by the analytical verb form (with the particle (ne)khay), as modally oriented structures provide the possibility to represent the different types of modality. They can equally implement different types of meanings, except the incentive, so they can have many semantic interpretations and functional purposes. To correctly determine the modal status, these constructions are poorly marked and require mainly the involvement of a speech-situational filter.

Keywords: modality, modal meaning, incentive structure, predicative basis, analytical verb form, structural-grammatical type, functional-semantic type. 


\section{Вступ}

Актуальність дослідження конструкцій з партикулою (не)хай зумовлена необхідністю встановлення чітких критеріїв розмежування понять і явищ, пов'язаних з репрезентацією в мові модально орієнтованих конструкцій, зокрема спонукальних, бажальних, розгляд яких у сучасному мовознавстві демонструє неоднозначність поглядів і контроверсійність тлумачень. Конструкції названого типу вимагають детального вивчення ще й через незначний обсяг теоретичних праць із зазначеної проблематики, що зі свого боку зумовлює відсутність остаточно з'ясованих питань щодо їх кваліфікації.

У сучасному мовознавстві конструкції з партикулою (не)хай здебільшого визнають спонукальними, грунтуючись переважно на категорійному значенні форми предиката. Однак орієнтація виключно на морфологічні показники спонукальності призводить до хибного тлумачення модальної сутності конструкцій та їхнього функційно-семантичного статусу. Аналіз мовленнєвого матеріалу засвідчує набагато ширшу палітру значень, окрім спонукального, що можуть виражати конструкції з названою формою предиката, а також множину додаткових відтінків, які нашаровуються на спонукальне значення й тісно переплітаються з ними.

Побіжно, у контексті дослідження широкого спектру модальних явищ, тему своєрідності заявленого типу конструкцій розробляли Г. А. Абросимова, Л. В. Бережан, Г. Г. Дрінко, А. М. Ломов, С. В. Мясоєдова та інші. Зокрема, специфіку спонукальних конструкцій з партикулою (не)хай пов'язують з виявленим явищем «модусу в модусі» (С. В. Мясоєдова), або «подвійним спонуканням» (А. М. Ломов), що дає підстави вважати їх непрямоспонукальними (Л. В. Бережан). На потребу розмежування спонукальних і неспонукальних конструкцій з партикулою (не)хай звернула увагу В. Ю. Стешевич. Конструкції, структуровані за допомогою предиката аналітичної форми дієслова із зазначеною партикулою, заслуговують на більш глибоке й детальне вивчення їхньої унікальної природи.

Метою статті є виявлення граматичної й модальної сутності конструкцій з партикулою (не)хай. Заявлена мета передбачає розв'язання таких завдань: визначення специфіки семантичного наповнення й особливостей функціонування відповідних висловлень як мовленнєвих репрезентантів окремих видів модальності, характеризація 
ознак мовленнєвої ситуації, релевантних для реалізації спонукальних та неспонукальних конструкцій.

\section{Методи дослідження}

У роботі використано описовий, трансформаційний методи, а також методи зіставлення й компонентного аналізу. Методика дослідження - аналіз мовного явища від рівня комунікативного, на якому формується модальне значення через його семантико-синтаксичну реалізацію, до рівня синтаксичного, де виявляються засоби формального й семантичного вираження модального значення.

\section{Виклад основного матеріалу}

Давно було помічено, що спонукальне значення в змісті описових форм із такою часткою конкурує з бажальним значенням (Шахматов, 1980: 483). Відзначають, що спонукання до дії, адресоване третій особі, об'єкту мовлення, завжди містить у собі експресивні відтінки допусту, дозволу, заборони або побажання (Виноградов, 1972: 453).

Дослідники звертають увагу на важливість лексико-семантичного наповнення конструкцій для правомірності віднесення їх до спонукальних чи бажальних. За умови суб'єкта-неістоти конструкції з хай, нехай тяжіють до послаблення спонукального значення, натомість виразним у них постає бажальне значення, наприклад: Нехай збирається на дощ, ми від своїх намірів не відступимо. Нехай йому щастить! (Романюк, 1999: 11). Водночас потребує уваги лексикосемантичне наповнення предиката. У прикладі Нехай живуть звитяжиі-молодиі! (І. Кочерга) нівелювання спонукального значення засвідчує нехарактерна для спонукальних конструкцій предикативна ознака, утілювана за допомогою статичного дієслова. Як відомо, такі предикати стану відбивають ознаки неконтрольованості. Очевидним $€$ девальвування здатності семантичного суб'єкта фізично вплинути на реалізацію названої ситуації: вона фактично не може бути підвладною людській волі та енергії, а тому є аномальною для спонукання.

Без лексико-семантичної підтримки процес інтерпретування синтаксичного статусу конструкцій з (не)хай видається більш складним і часто потребує залучення аналізу широкого мовленнєво-ситуаційного контексту.

Для коректної функційно-семантичої регламентації аналізованого структурно-граматичного типу конструкцій важливим видається 
урахування сутнісних ознак спонукальності, оптимізованих у спонукальних конструкціях і нівельованих в усіх інших. Вихідним положенням для вирізнення серед загалу аналітичних конструкцій аналізованого формально-синтаксичного типу саме спонукальних $€$ розуміння їхнього специфічного функційного призначення, яке полягає в спонуканні до виконання дії якоюсь особою, що зі свого боку зумовлює сутність спонукальних конструкцій. Спрямовані на зміну конкретної реальності через посередництво особи адресата-потенційного діяча, вони заздалегідь спроєктовані для впливу на поведінку останнього.

Опосередковане спонукання, утілене в таких непрямих спонукальних конструкціях, виявляє всі характерні для відповідного значення риси, передбачені наявністю в їхньому семантичному змісті основних конституентів спонукальної семантики, як-от: адресованість, апелятивність, каузативність, волюнтативний вплив, націленість на результат, регулятивність. Зміст спонукання потенційного діяча до дії через посередника можна експлікувати в такий спосіб: Нехай він зробить ие = Скажи йому, щоб він зробив це або Зроби так, щзоб він зробив изе.

Прикладом реалізації спонукальної функції засобом речень названого структурно-синтаксичного типу можуть бути такі ілюстрації: (імператор до проедра з метою узяти власного історіографа у воєнний похід) -<..> Поклич Льва, поговори з ним і дай йому срібну чорнильниию. Нехай вирушає разом із нами (С. Скляренко); I переказував. I попереджав! Готуйтеся! Набивайте гаківнииі і мушкети, сідлайте вороних коней! Хай пильнують дозориі на сторожових вежах у степу і вчасно підпалять бочку з смолою - знак, що в полі з'явився ворог (В. Малик); Чи квасолі, чи гороху треба буде - беріть, скільки схочете: у нас все рівно ніхто не їсть, а вам, може, для пирогів здасться. Нехай Христя іде за мною, бо мені пора, - досі дитина прокинулась, - та й візвме, скільки там треба (Панас Мирний).

Орієнтація на виконання конкретних дій і запускання їх реалізації засобом висловлювання створює сприятливе тло для інтерпретування відповідних конструкцій як спонукальних.

Існують синтаксичні конструкції з (не)хай, у змісті яких репрезентовано ірреальну ситуацію, орієнтовану не на зміну реального стану речей, а, навпаки, на прийняття теперішнього. Фактом висловлювання 
мовець сигналізує про існування ситуації, на яку найчастіше не може вплинути через об'єктивні обставини. Він не намагається спонукати когось змінити іiі, а лише повідомляє про своє ставлення до ситуації, що вже існує. Ситуація не залежить від волі мовця, що зумовлює неконтрольованість ії здійснення. Суб’єктові мовлення залишається прийняти дійсний стан речей. Ця акцепція може бути схвальною, вимушеною або взагалі індиферентною. У будь-якому разі йдеться про згоду мовця на існування й можливе продовження конкретного стану речей. Таку мовленнєву ситуацію пов'язують з вираженням так званого нонкуратива, або семантики невтручання (Добрушина, 2008: 142; Стешевич, 2014: 281), наприклад:

- Пізно буде. Он уже місяць сідає, - одказала Христя.

- Хай сідає. Хіба і без нього не видко шляху? Коли бойися - проведемо, - кажуть парубки (Панас Мирний);

- Кажуть таке.. тьфбу! Я б ім язика одрізала, щзоб не брехали!.. Кажуть - либонь, тебе якийсь панич присоглаша на село. Чи можна таке вигадати! - гаряче засипала Христя.

- Хай вигадують!.. - зітхнувши важко, одказала Марина (Панас Мирний).

Залучення контекстуального фільтру для аналізу функціонально-семантичної специфіки конструкцій з (не)хай дає змогу виявити в окремих 3 них значення поступки. Мовознавці відзначають складність розмежування значень невтручання і поступки через те, що джерелом розвитку останнього $є$ саме нонкуративні контексти (Добрушина, 2008). Такі конструкції пропонують результат прихованого внутрішнього компромісу мовленнєвого суб'єкта. Опинившись у ситуації, протилежній до його очікування, він усе ж таки оцінює наявний стан речей як прийнятний. Звертаючи увагу на позитивний бік справи, мовець змушує себе схвалити подальший перебіг подій і висловлює особисту згоду на здійснення певної ситуації, сигналізуючи про своє ставлення до неї як до необхідної, корисної, потрібної. Важливою $є$ при цьому відсутність будь-якого запиту з боку якоїсь особи на підтримку або заборону щодо здійснення названої ситуації, ба більше, суб'єкт дії здебільшого перебуває поза межами наявного мовленнєвого процесу. Висловлення такого змісту частіше фігурують в автореферентному мовленні. 
Ілюстрацією аналітичних конструкцій зі значенням поступки, які слід відрізняти від спонукальних, є такі приклади:

- Як гуляють наші гості? - запитав Святослав.

- Зачали добре, - відповів Добриня, - днів три тепер похмелятимуться.

- Нехай погуляють, - посміхнувся Святослав. - $Є$ в нас чим прийняти й повеселити гостей (С. Скляренко);

Та Борис був хлопець хоч куди. Що ота зачіска та танцюжки чи браслети із шкіри? То пусте! Мало хто що одягає. Молоде, перебіситься, а гітара, так то ж музика, хай гуляє, а що кричать вони, так то молода дурість! Викричаться й минеться! Аби не хуліганили, не впивались, не крали та не бешкетували. А співають чи таниюють, то нехай собі! Коли ж бо їм молодими бути. Так і батько казав, i мати (Д. Покальчук).

Висловленням такого типу часто передують фразеологізовані вигуки на взірець Біс із ним, що додатково підкріплює їх значення, одразу попереджаючи про змушену поступливість мовця, наприклад: Вони відокремились, щзоб відокремити мене від Галичини. Але $і$ я дурний. Сказав би, що стомився. Ні, моя поступливість завжди доводить донепорозумінь. Спершу я подаю людям надію, а тоді підбирається така ситуачія, що я мушу їх розчарувати. "Я вважаю за краще помилятися сам, ніж з мудреиями і иілим світом", - написав би в наші дні один франиуз. Біс із ними. Нехай відокремлюють. Крім них, єще логіка життя (Р. Андріяшик).

Якщо мовець демонструє добровільне прийняття ситуації у відповідь на конкретну діалогову репліку, то конструкція з (не)хай, використана для оформлення цього змісту, функціонує в значенні поступки-згоди. На відміну від спонукальних конструкцій зі значенням згоди, що є результатом попереднього стимулу до спонукання реципієнта, ці конструкції відповідають на запити, не орієнтовані на отримання дозволу / погодження щодо здійснення третьою особою певної дії. Мовець лише повідомляє про схвалення, переважно вимушене, певної картини дійсності, нікого не спонукаючи до конкректної дії. У таких конструкціях агентивний суб’єкт може бути взагалі відсутнім, що зумовлює безособовість предикативної одиниці - однокомпонентного речення-репрезентанта. Автор висловлення актуалізує ті структурні компоненти, які вважає семантично значущими, що 
характерно для сфери розмовного мовлення, передусім діалогового спілкування. В ізольованому використанні такі конструкції втрачають інформативну достатність, наприклад:

Література - ие делікатна річ, - додав він переконано. - Руку треба мати, а то й не підступайся. Того й письменників мало, я думаю.

Борис не згоджувався:

- То ице, по-твоєму, як посада?

- Похоже.

- Дурний.

- Хай (В. Підмогильний).

Значення поступки отримує більш рельєфний прояв у разі зіставлення двох ситуацій, що суперечать одна одній. За допомогою конструкції з (не)хай мовець повідомляє про те, що приймає факт існування ситуації, незважаючи на те, що вона оцінена ним негативно. Проте він погоджується на ії реалізацію заради здійснення іншої ситуації, визначеної як необхідна, корисна, бажана. Потреба у вербалізації двох пропозицій для вираження названого значення зумовлює звичне включення такої конструкції до складу поліпредикативної одиниці, де синтаксична частка (не)хай набуває значення слова-зв'язки, наприклад: Б и ч о к. Нехай мене замість дяки кленуть, нехай навіть плюють мені межи очі, а я з свого шляху не зверну!.. (М. Кропивницький); Шепталові раптом захотілося почути голос конюха. Хай він буває інколи злим, але ж при службі, та ще з такими кіньми, як у них, з ким не буває (В. Дрозд); Хай хоч мур завалиться, а не дам! (В. Винниченко).

Конструкції з (не)хай, функціонуючи в структурі поліпредикативної одиниці або складного синтаксичного цілого преференційного змісту, виражають значення поступки-згоди й демонструють так званий псевдовибір суб'єкта мовлення. Ідеться про зіставлення двох оцінюваних ситуацій і надання переваги одній з них за принципом вибору меншої з двох бід. Мовець висловлює згоду на реалізацію однієї, менш негативної в порівнянні з іншою ситуації, заради нездійснення ще гіршої, на його розсуд, ситуації, свідомо применшуючи недоліки першої, наприклад: Ну, хай уже я з'їхав з глузду, хай та жінка $з$ ї̈ горіхами, хай той “син Горбачова» з ретранслятором уживоті, але уряди, президенти, наділені владою лідери, - куди ж вони ведуть 
людей і народи?! (Л. Костенко); - Що ж, - зауважив інструктор, от, приміром, клубна робота. Серйозне діло. I так робітники носом крутять - сухо, кажуть. А тут ще мова. Ну, ще драмгурток, хай $\boldsymbol{x о р - а ~ д а л і ~ т п р у ~ ( В . ~ П і д м о г и л ь н и и ̆ ) . ~}$

Значення поступки-згоди як псевдовибору виражають конструкції з (не)хай, функціонуючи в структурі поліпредикативної одиниці (або складного синтаксичного цілого) із зіставно-протиставним відношенням, де контрастний фон створений за принципом «виключно важливе - менш важливе». Мовець погоджується на реалізацію не досить прийнятної для нього ситуації, оцінюючи ії як несуттєву (або малозначну) на момент мовлення порівняно з тією, що $є$ предметом інтенсивного бажання, наприклад: На вулищю. Хай там немає повітря, хоча 6 люди... Поспішають собі - сумні, веселі... (Люко Дашвар); А зрештою махнув рукою. Аби лише не прибили того дурака на смерть. Хай брикає... (І. Багряний).

Конструкції з (не)хай придатні для вираження так званого наукового припущення, за якого мовець повідомляє про деяку ймовірну ситуацію як потенційно припустиму. Наприклад, в умові математичної задачі конструкція Хай а дорівнює $b$ означає Припустимо, щзо $a$ дорівнює $b$. У сфері розмовного мовлення конструкції такого функційно-семантичного типу виходять за межі наукового абстрагування, утілюючи суб'єктивне відображення конкретної картини дійсного світу речей. Розмірковуючи над планом майбутньої реальності, мовець, якого це безпосередньо стосується, повідомляє про своє ставлення до дійсності й пропонує власне бачення вірогідного перебігу подій: - Поїздка на Січ, а потім до Корсуня займе не більше десяти днів... Хай навіть два тижні... Але ж ми звідси теж будемо добиратися до Корсуня днів п'ять... Тож за ией час, треба сподіватися, з твоїми рідними, Арсене, нічого не трапиться (В. Малик).

Близькість до названого значення виявляють конструкції з (не)

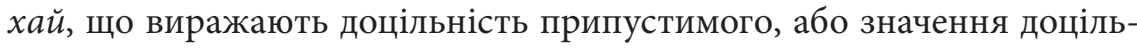
ного припущення: Тоді князь Святослав ще раз радився з матір'ю, запросивщи до розмови воєводу Свенелда й брата Уліба.

- Вже повно води в Дніпрі, - говорив князь Святослав, - $і$ лодіі наші, як птахи, пролетять через пороги. Але, думаю я, не токмо Дніпром рушимо ми по Дунаю. Частина війська нашого нехай іде борзно 
й пішо через поле, Тиверську й Углицьку землі, а там з'єднаємось і перейдемо Дунай.

- То добре, княже, - згодився Свенелд, - і так більше поставимо над Дунаєм сил. А пішо пройдемо безпечно, в полі тихо, тивериі й угличі ще дадуть нам підмогу, - вели рушати, не гай часу, княже! (С. Скляренко).

Художній уривок з описом історичної наради яскраво демонструє функціонування конструкції з нехай не в спонукальному значенні, а в значенні доцільного припущення. Мовець не має на меті перекласти обов'язок щодо здійснення конкретної ситуації на слухачів. Він пропонує на їхній розсуд інформацію про перебіг власних міркувань щодо необхідної воєнної стратегії. Очікуваною є зворотна реакція реципієнта - схвальне оцінювання думок адресанта, але неготовність переказати групі третіх осіб волю адресанта, яку мала б передбачати спонукальна конструкція. Показово, що втіленню намірів героя (князя) в життя (дію) сприяє дотримання відповідного комунікативного напряму на шляху до реалізації передбачуваної (доцільної) картини дійсності: вели рушати, не гай часу, княже! Попередню конструкцію з нехай безпосередні отримувачі також не сприйняли як формально спонукальну, достатню для того, щоб розпочати військовий похід.

Сумнівним видається віднесення до спонукальних конструкцій типу Нехай це вас не хвилює, у змісті яких убачають контамінацію значень спонукальності та повинності (Шведова, 1980: 115). Відсутність активного суб'єкта предикативної дії проблематизує реалізацію передбачуваного спонукання. За смислом конструкція більше тяжіє до моделі дебітивної сфери модальності Це не повинно тебе хвилювати, ніж спонукальної Не хвилюйся. Наявність компонента «повинність» не взаємозумовлює спонукальність. Повідомлення про те, що необхідно / повинно бути реалізованим, може не передбачати звернення до адресата з метою спонукання. Художні ілюстрації функціонування таких конструкцій у розмовному мовленні увиразнюють викладене положення:

(Старий кошовий перед смертю): - ... Лишається сказати ще одне: хотів би я знати, кому ви вручите після мене булаву кошового? $<\ldots>$

- Хай ие тебе не турбує, Іване, - сказав після тривалої мовчанки Стягайло. - Виберемо достойного! (В. Малик). 
Така форма звернення до адресата зумовлена принциповим вибором мовця. Із граматичного погляду органічним утіленням звернення до другої особи є використання прямої спонукальної конструкції Не турбуйся, Іване. Проте, передбачаючи іншу інтенцію, автор висловлення послуговується саме аналітичною конструкцією. Як видно, мовець має на меті не заспокоїти слухача, дбаючи про позбавлення останнього певного психологічного дискомфорту й розділити в такий спосіб його переживання, морально підтримати. Смисл, закладений у змісті аналізованих конструкцій, полягає у вказівці на конкретну ментальну поведінку слухача, яка повинна, з погляду мовця, бути реалізованою на противагу тій, що на момент мовлення його не влаштовує. Відбувається своєрідна вербальна відсіч, за якої слухачеві не досить увічливо повідомляють про те, що він порушив нормативні параметри комунікації, як і в прикладі:

$-<\ldots>$ Звідки й куди прямуєш?

- Хай ие вас не иікавить, добродію... Де був, там уже немає. Куди прямую, там не ждуть! - відповів різко Арсен (В. Малик).

До вираження дебітивного значення тяжіють і такі конструкції: «E-e, будь що буде! - подумав Кучук <плануючи вкрасти двох дівчат для гарему>. - Не випущу з рук ту золотокосу пташину!.. Обох - небезпечно. А одну - Стеху... Хіба, може, ладком домовитися з Многогрішним? Невже старий пес відмовиться від грошей?.. Тоді хай нарікає на самого себе! Перейму в степу - вирубаю всіх до ноги! Щоб жодного свідка не лишилося! А дівчата - в такому випадку обидві - стануть моїм ясиром!» (В. Малик).

Звертає на себе увагу лексико-граматична особливість конструкцій - наявність займенникових іменників сам, себе. Наявність їх сигналізує про відсутність наміру з боку мовця бути особисто залученим у названий ним процес реалізації дійсності.

Конструкції з (не)хай можуть репрезентувати значення умови в контексті вираження уявної погрози об’єктові передбачуваного негативного впливу, як-от покарання: «Надвір, видно, пішла, бо сінешні двері не щільно причинені. Ну, хай же увійде», - каже сама собі пані i, одкривщи макортет, заглядає усередину (Панас Мирний). Передумовою виникнення висловлення є досить тривалий процес пошуку мовцем необхідного йому об'єкта зацікавлення. Розлючена пані акумулює силу свого негативного враження від отриманого факту 
дійсності в завершальній частині внутрішнього монологу. Зрозуміло, що конструкція за змістом передбачає певний наслідок від реалізації названої ситуації: Хай (коли) увійде, (mоді) зроблю, експлікація якої видається семантично надлишковою. Тривіальна життєва ситуація очікуваного покарання, за якої природним $є$ використання такої конструкції, позбавляє необхідності вербалізації ії повного компонентного складу. Вона цілком зрозуміла для пересічного українського слухача, оскільки є знайомою з дитинства формою батьківського емоційного реагування на результат негативної поведінки малого бешкетника, відсутнього на момент мовлення: Хaй тільки прийде!; Хaй поговорить у мене!; Хай тільки спробує!

У ситуації, яка потребує роз'яснення, а тому й омовлення прогнозованого наслідку, складова частина, що містить його, стає експлікованою. Зокрема, у прикладі вираження погрози з метою заспокоєння скривдженого третіми особами слухача й запевнення його у вірогідній безуспішності прогнозованої поведінки перших мовець указує на потенційні подальші події, зумовлені нею: - Не журіться, mimко! - утішає Карпо. - Хай вони поткнуться до миру... Я перший почну гукати! Не їх дукачів мир послухає. <...> Не послухає їх мир. Ніколи! <...> Ще побачимо, чий батько стариий! Їх три, а нас сотня. $<\ldots>$...Не журіться! (Панас Мирний). Як видно, мовець не має наміру спонукати слухача до сприяння реалізації названого й конструкція не може бути інтерпретована як спонукальна Скажи їм / зроби так, щзоб вони поткнулись до миру.... Сюжет твору доводить, що здійснення названої ситуації взагалі не в інтересах героя-мовця. Погроза-виклик Хай вони поткнуться до миру... є результатом попереднього натиску від соціального супротивника: Уже коли на мир пішло, то ми твій мир і в чорну запремо.

А от приклад вираження умови в контексті погрози передбачуваному суперникові в поєднанні з вихвалянням:

- <..> Xто попав під мій покров, ой безпечний, як у Господа за пазухою.

- Та коли б сюди наспіла княжа погоня, гайдуки, так...

- Начхати мені на твого князя і його гайдуків. Хай попробує мене взяти. Не доказала того орда, скільки разів собі зуби вищербила, не візьмуть й княжі гайдуки. Шкода, щ, ти, письменний, та таке верзеш (А. Чайковський). Мовець нікого не спонукає до виконання 
названої дії та іiі переадресації. Засобом питомої конструкції він намагається засвідчити власну непоборність (Він мене не візьме), на що додатково вказують його подальше повідомлення про минулі та майбутні перемоги, до того ж фінішна фраза переконливо доводить надмірну самовпевненість мовця. У змісті конструкції Хай попробує мене взяти міститься умова для здійснення наслідку, який настільки очевидний, що не потребує експлікації: Якщьо він попробує мене взяти, то отримає гарантовану відсіч.

За допомогою конструкції з (не)хай висловлюють обіцянку щодо виконання в майбутньому затребуваної з боку слухача дії. Суб'єктом виконання при цьому є мовець, який покладає на себе відповідальність за визначення важливості й необхідності у здійсненні названого: «А яку я пісеньку склала про свою журбу! Нехай колись тобі заспіваю» (М. Кропивницький); < .. > Їй <Христі > страх як хотілося розказати Мар'ї усе. <...> «Нi, не сьогодні, подумала Христя. - Хай колись...» (Панас Мирний);

- Ви тільки ї заставте; вона все розкаже.

- Добре, добре, - хмурячись, одказує панич. - Нехай ще другим разом, тепер я втомився (Панас Мирний).

Помітною семантичною ознакою конструкцій з (не)хай, використаних у значенні обіцянки, $є$ відносна довільність передаваного зобов'язання. На відміну від категоричного Я зроблю, у реальності майбуття якого впевнений мовець, конструкція Нехай я зроблю завдяки формі представлення власне ірреальної дійсності, у здійсненні якої мовець не може бути впевнений, знімає з останнього відповідальність за виконання / невиконання обіцяного й позбавляє його потреби коритися власному моральному тиску. Тому частотним виявляється акцентуація на невизначеності конкретного плану майбутнього здійснення: колись, другим разом.

\section{Висновки}

Синтаксичні конструкції із предикатом, актуалізованим аналітичною формою дієслова $з$ партикулою (не)хай, як модально орієнтовані конструкції передбачають можливість репрезентації різних видів модальності: спонукальної, бажальної та інших. Вони однаково активно можуть реалізовувати різні види значень (не лише спонукального), тому припускають множинність інтерпретації їхньої 
семантики й функційного призначення. У плані репрезентації спонукальної модальності ці конструкції є слабо маркованими й потребують здебільшого залучення мовленнєвоситуаційного фільтра.

Природа непрямого, опосередкованого спонукання виявляє дещо завуальований характер волюнтативних відношень між мовцем і потенційним діячем, що вимагає залучення додаткових критеріїв регламентації. Ідентифікатором функційно-семантичного типу синтаксичної одиниці здебільшого виступає конкретний мовленнєвий контекст, в умовах якого відбувається ії реалізація. В ізольованій позиції вона виявляє конкурентоспроможність альтернативних потрактувань іiі функційно-семантичного статусу. Зміст і мета застосування синтаксичних конструкцій з (не)хай часто виявляються ситуативно зумовленими. Як засвідчують приклади, конструкції такої форми слугують не тільки для вираження спонукального значення, а й виконують інші функції, наприклад, вираження бажання, допусту, невтручання, поступки, згоди, умови, повинності, погрози, наукового припущення, допустового припущення, обіцянки. Основними відмінними рисами спонукальності, що в разі реалізації неспонукальних конструкцій не виявляються або нівельовані, $є$ націленість на результат, вплив на вольову сферу слухача, спрямованість на керування його поведінкою. Зміст спонукальної конструкції передає умовна модель Скажи йому, щоб він зробив ие або Зроби так, щоб він зробив ие. Пропонований опис неспонукальних конструкцій з (не)хай ілюструє викладені положення, проте не претендує на вичерпний аналіз усіх можливих функційно-семантичних типів, що становить перспективу подальших досліджень.

\section{ЛІТЕРАТУРА}

1. Виноградов, В. В. (1972). Русский язык: Грамматическое учение о слове. Москва: Высшая школа. 2. Добрушина, Н. Р. (2008). Статус конструкций с частицами пусть и пускай в русском языке. В Исследования по теории грамматики (с. 135-160). Москва: Гнозис. 3. Романюк, Т. М. (1999). Парадигматика простого речення в сучасній українській мові. (Автореф. дис. ... канд. філол. наук). Тернопіль: Терноп. держ. пед. ун-т ім. Володимира Гнатюка. 4. Стешевич, В. Ю. (2014). Способы побуждения 3-го лица в русском и сербском языке. Проблемы истории, филологии, культуры, 2 (44), 277-285. 5. Шахматов, А. А. (1941). Синтаксис русского языюка. Ленинград: Гос. уч.-пед. изд-во Наркомпроса. 6. Шведова, Н. Д. (Ред.). (1980). Русская грамматика. (Т. 2). Москва: Наука. 


\section{REFERENCES}

1. Vinogradov, V. V. (1972). Russkij jazyk: Hrammaticheskoe uchenie o slove [Russian language: The grammatical doctrine of the word]. Moskva: Vysshaja shkola [in Russian]. 2. Dobrushina, N. R. (2008). Status konstruktsiy s chastitsami pust' i puskay v russkom yazyke [The status of structures with particles pust' and puskay in Russian]. In Issledovaniya po teorii grammatiki - Studies in grammar theory (pp. 135-160). Moskva: Gnozis [in Russian]. 3. Romanyuk, T. M. (1999). Paradyhmatyka prostoho rechennia v suchasnii ukrayinskii movi [Paradigmatics of a simple sentence in the modern Ukrainian language]. Extended abstract of candidate's thesis. Ternopil: Vladimir Hnatiuk Ternopil State Pedagogical University [in Ukrainian]. 4. Steshevich, V. YU. (2014). Sposoby pobuzhdeniya 3-go litsa v russkom i serbskom yazyke [Ways to induce a 3rd person in Russian and Serbian]. Problemy istorii, filologii, kul'tury - Problems of history, philology, culture, 2 (44), 277-285 [in Russian]. 5. Shaxmatov, A. A. (1941). Sintaksis russkogo yazyka [Russian syntax]. Leningrad: Uchpedgiz [in Russian]. 6. Shvedova, N. D. (Ed.). (1980) Russkaya grammatika [Russian grammar]. (Vol. 2). Moskva: Nauka [in Russian].

Умрихіна Любов Володимирівна - кандидат філологічних наук, доцент, доцент кафедри українознавства та лінгводидактики, Харківський національний педагогічний університет імені Г. С. Сковороди; вул. Валентинівська, 2, м. Харків, 61168, Україна.

Тел.: +38-096-29-19-423

E-mail: lubovumrikhina@gmail.com

orcid.org / 0000-0003-3888-342X

Umrykhina Liubov Volodymyrivna - Ph.D. in Philology, Docent, Associate Professor at the Department of Ukrainian Studies and Applied Linguistics, H. S. Skovoroda Kharkiv National Pedagogical University; Valentynivska Str., 2, Kharkiv, 61168, Ukraine.

Надійшла до редакції 06 вересня 2020 року

\section{CITATION}

ДСТУ 8302:2015: Умрихіна Л. В. Функційно-семантична диференціація конструкцій з партикулою (не)хай. Лінгвістичні дослідження: зб. наук. пр. Харк. нац. пед. ун-ту імені Г. С. Сковороди. Харків, 2020. Вип. 53. С. 141-154. DOI: https:/doi.org/ $10.34142 / 23127546.2020 .53 .13$

AРА: Умрихіна, Л. В. (2020). Функційно-семантична диференціація конструкцій $з$ партикулою (не)хай. Лінгвістичні дослідження, 53, 141-154. DOI: https:/doi.org/ $10.34142 / 23127546.2020 .53 .13$ 